\title{
FACTORS THAT SATISFY THE USERS OF APP CABS IN A COVID STRICKEN NATION: AN INSIGHT INTO URBAN INDIA
}

\author{
Dr Swapna Datta Khan ${ }^{1}$ \\ Assistant Professor, Army Institute of Management, Kolkata, India
}

Ms Deepa Meel ${ }^{2}$

Aspiring Research Scholar (applied to MAKAUT), India

Article DOI: https://doi.org/10.36713/epra6674

\begin{abstract}
The SARS Co V19 virus touched India in early 2020 and by March 20 the entire nation was in the process of observing a strict lockdown. The Covid 19 protocol in urban India came with a slew of restrictions on the citizens' movement and traffic within cities. In May 2020, the lockdown was eased and the App Cab businesses of the Transportation Sector issued instructions to combat the pandemic while yet ferrying urban commuters efficiently, such as the compulsory sanitization of vehicle after each trip and a stringent check on the health records and hygiene levels of their drivers. In this paper, the 22item multidimensional SERVQUAL instrument was used to generate an initial construct and Exploratory Factor Analysis revealed an underlying construct throwing light $n$ the drivers of user satisfaction with relation to App Cab commute in Indian cities.

KEY WORDS: Construct, Covid 19, Pandemic, App Cab, Customer Satisfaction, SERVQUAL
\end{abstract}

\section{INTRODUCTION}

In 2020, the SARS CoV19 touched India in March and the Central and State Governments imposed strict lockdown to stem the transit of the deadly virus. After May 2020, the lockdown was eased, commercial activities were re-introduced and citizens moved outside for necessities, albeit warily. At this time the App Cab companies introduced a slew of measures to abide by the newly introduced Covid protocol and yet satisfy the customer. This paper throws light on the factors that drive customer satisfaction of App Cabs in Indian cities in these trying times.

\section{LITERATURE REVIEW}

Covid-related measures taken by the two major Indian App Cab companies

Uber: Pandemic related measures taken for safer travel by Uber App Cab are as follows: a) Only two occupants are allowed at a time to ensure social distancing. Thus, Uber Pool facility of a pool-cab system was suspended

b) Hygiene supplies are provided to each car and the driver has to sanitize the car after each ride

c) Besides, Uber supported health-care by providing free services to health-care workers, providing free meals and ferrying medical supplies

d) Both riders and drivers have to wear face masks all the time

e) A photo-based verification of driver each time they $\log$ in, where the driver has to photograph himself wearing a mask and the camera detects the same

f) The ride can be cancelled by either driver or rider in case a mask is not worn

(Our approach to COVID-19, n.d.), (Uber announces new safety features amid COVID-19, masks now mandatory for both driver and riders, 2020) 
Ola: Pandemic related measures taken for safer travel by Uber App Cab are as follows:

a) The ride can be cancelled by either driver or rider in case a mask is not worn

b) Hygiene supplies are provided to each car and the driver has to sanitize the car after each ride

c) To maintain social distancing, customers have to handle their own luggage

d) Payments are only cashless

e) Only two occupants are allowed at a time to ensure social distancing

f) A mask-recognition camera system is installed

g) Mandatory integration with the Arogya Setu App

h) Training of drivers in following hygiene protocols

i) Monitoring of driver well being

j) An open request to public to give inputs on how hygiene standards could be improved

k) $\mathrm{AC}$ to be switched off to ensure adequate ventilation

(Ola Cabs: Ride Safe, n.d.), (Ola launches '10 Steps to a Safer Ride' for driver-partners and customers as services resume in $100+$ cities in green and orange zones across the country, n.d.)

\section{Similar Studies}

In their study, Bhuvaneswari, Varghese, Rajasekaran, \& Muthulakshmi, 2018, analyzed the factors affecting customer retention and proved that the growth of digital marketing efforts in the geographical area of Coimbatore city. They emphasized that security, information quality and perceived usefulness would bridge the gap between demand and supply. (Bhuvaneswari, Varghese, Rajasekaran, \& Muthulakshmi, 2018)

Thilakaratne \& Jayaratne, 2019 studied the factors that affect user satisfaction for the app cabs in India. And emphasized on professionalism of service, affordability, reliability, travel-time efficiency and safety. (Thilakaratne \& Jayaratne, 2019)

Ghosh \& Mitra, 2019, analyzed the sentiments of App Cab drivers in Kolkata with the aim of identifying issues. They noted that meeting customer expectations and earning satisfaction have an impact on the drivers' satisfaction levels. The drivers were dissatisfied with improper calculation of cancellation fees and the possible blocking of accounts. The drivers also mentioned the need for sturdier methods of compensation and safety mechanisms. (Ghosh \& Mitra, 2019)

Pandya, Rungta, \& Iyer, 2017 noted that with the advancement of technology, the app cabs had given serious competion to the traditional taxi services in Indian cities due to the variety of payment options, the possibility of vehicle tracking and the $24 \times 7$ service. (Pandya, Rungta, \& Iyer, 2017)

Le-Klähn, Hall, \& Gerike, 2014 analyzed the user satisfaction of the public transport systems of Munich. They noted that information, ticket price, service frequency, comfort and ease-of-use drove user satisfaction levels at Munich. (Le-Klähn, Hall, \& Gerike, 2014)

Sivasakthi, Nandini, Priyadharshini, \& Vanathi, 2019 studied the taxi services available in India and said that people preferred app cab services as a necessary luxury and feel justified for the tarriff levied. (Sivasakthi, Nandini, Priyadharshini, \& Vanathi, 2019)

\section{OBJECTIVE}

Research objective (in the pandemic-stricken environment)

a) To reveal the drivers of consumer satisfaction of the urban India consumer of the App Cab

b) To throw light on the satisfaction levels as observed through the primary data

\section{RESEARCH METHODOLOGY}

Many methods of the measurement of Service Quality and Customer Satisfaction in the Services Sector have evolved. However, the 22-item multidimensional SERVQUAL instrument developed by Parasuraman et al. is yet relevant and most prominent and has been used by a Focus Group to decide on the set of initial variables. (Buttle, 1996) 35 initial variables (as depicted in Table 1), so decided, were measured using Likert Scores and options as: Strongly Disagree/ Disagree/ "I am OK"/ Agree/ Strongly. "Customer Satisfaction", here has been synonymized with "Service Quality", and is approached holistically, keeping the SARS CoV19 virus pandemic as a backdrop. Thus the 35 initial variables are generalized and are measured in the backdrop of the pandemic. The questionnaire, so created was thrown open (using Google Forms) to a snowball sample of 146 respondents. The genuine data of 146 responses fell short to facilitate Exploratory Factor Analysis and thus was simulated to create a database of size 561 to enable analysis. Demographic details of city of residence were noted are depicted by Figure 1, using the classification of Indian cities into $X$, Y, Z (based on the 2001 census of India and reclassification in 2008). (Classification of Indian cities, 2021) 


\begin{tabular}{|c|c|c|c|c|}
\hline Sno & $\begin{array}{l}\text { SERVQUAL } \\
\text { Acronym }\end{array}$ & Question & Sub Question or Variable Details & Variable Name \\
\hline 1 & \multirow{7}{*}{ Reliability (Rel) } & \multirow{2}{*}{$\begin{array}{l}\text { Providing services as promised } \\
\text { (Promise) }\end{array}$} & $\begin{array}{l}\text { The App Cab reaches me within an } \\
\text { appropriate time }\end{array}$ & Rel_Promise1 \\
\hline 2 & & & $\begin{array}{l}\text { The App Cab takes me to my destination as } \\
\text { promised }\end{array}$ & Rel_Promise2 \\
\hline 3 & & \multirow{2}{*}{$\begin{array}{l}\text { Dependability in handling customer } \\
\text { service problems }\end{array}$} & $\begin{array}{l}\text { The App Cab Customer Care responds } \\
\text { whenever I have contacted them }\end{array}$ & Rel_Dependability1 \\
\hline 4 & & & $\begin{array}{l}\text { The App Cab Customer Care has always } \\
\text { solved my problem }\end{array}$ & Rel_Dependability2 \\
\hline 5 & & Provides Services at the correct time & The App Cab arrives promptly when called & Rel_Prompt \\
\hline 6 & & \multirow{2}{*}{ Maintaining Error Free Records } & $\begin{array}{l}\text { My profile in the App is always correctly } \\
\text { updated }\end{array}$ & Rel_Record1 \\
\hline 7 & & & $\begin{array}{l}\text { The App has an undertaking that the } \\
\text { passenger is not suffering from Covid or } \\
\text { Covid-related ailment }\end{array}$ & Rel_Record2 \\
\hline 8 & \multirow{3}{*}{$\begin{array}{l}\text { Responsiveness } \\
\text { (Res) }\end{array}$} & \multirow{2}{*}{$\begin{array}{l}\text { Keeping customers informed about } \\
\text { when services will be performed }\end{array}$} & $\begin{array}{l}\text { The App informs me about the time when } \\
\text { the Cab should be expected }\end{array}$ & Res_Info1 \\
\hline 8 & & & $\begin{array}{l}\text { The App informs me about the time when } \\
\text { the Cab would reach }\end{array}$ & Res_Info2 \\
\hline 10 & & $\begin{array}{l}\text { Readiness to respond to customer } \\
\text { enquiries }\end{array}$ & $\begin{array}{l}\text { Whenever I have asked the driver a } \\
\text { question, he has eagerly answered me } \\
\text { correctly }\end{array}$ & Res_Answer \\
\hline 11 & \multirow{5}{*}{ Assurance (Ass) } & \multirow{2}{*}{$\begin{array}{l}\text { Employees who instill confidence in } \\
\text { customers }\end{array}$} & $\begin{array}{l}\text { I always feel confident about the driving } \\
\text { skills of the driver }\end{array}$ & Ass_Emp1 \\
\hline 12 & & & $\begin{array}{l}\text { Whenever I have interacted with the } \\
\text { customer service of the App Cab, I have felt } \\
\text { confident regarding their efforts }\end{array}$ & Ass_Emp2 \\
\hline 13 & & $\begin{array}{l}\text { Making customers feel safe in their } \\
\text { transactions }\end{array}$ & The payment system is transparent & Ass_Paymt \\
\hline 14 & & \begin{tabular}{|l} 
Employees who are constantly \\
courteous
\end{tabular} & $\begin{array}{l}\text { The driver of the App Cab is always } \\
\text { courteous }\end{array}$ & Ass_Courtesy \\
\hline 15 & & Employees have the knowledge to & $\begin{array}{l}\text { The driver has knowledge about the App } \\
\text { and the Cab system }\end{array}$ & Ass_EmpKnow1 \\
\hline
\end{tabular}

Table 1: List of 35 initial variables, as decided by the Focus Group 


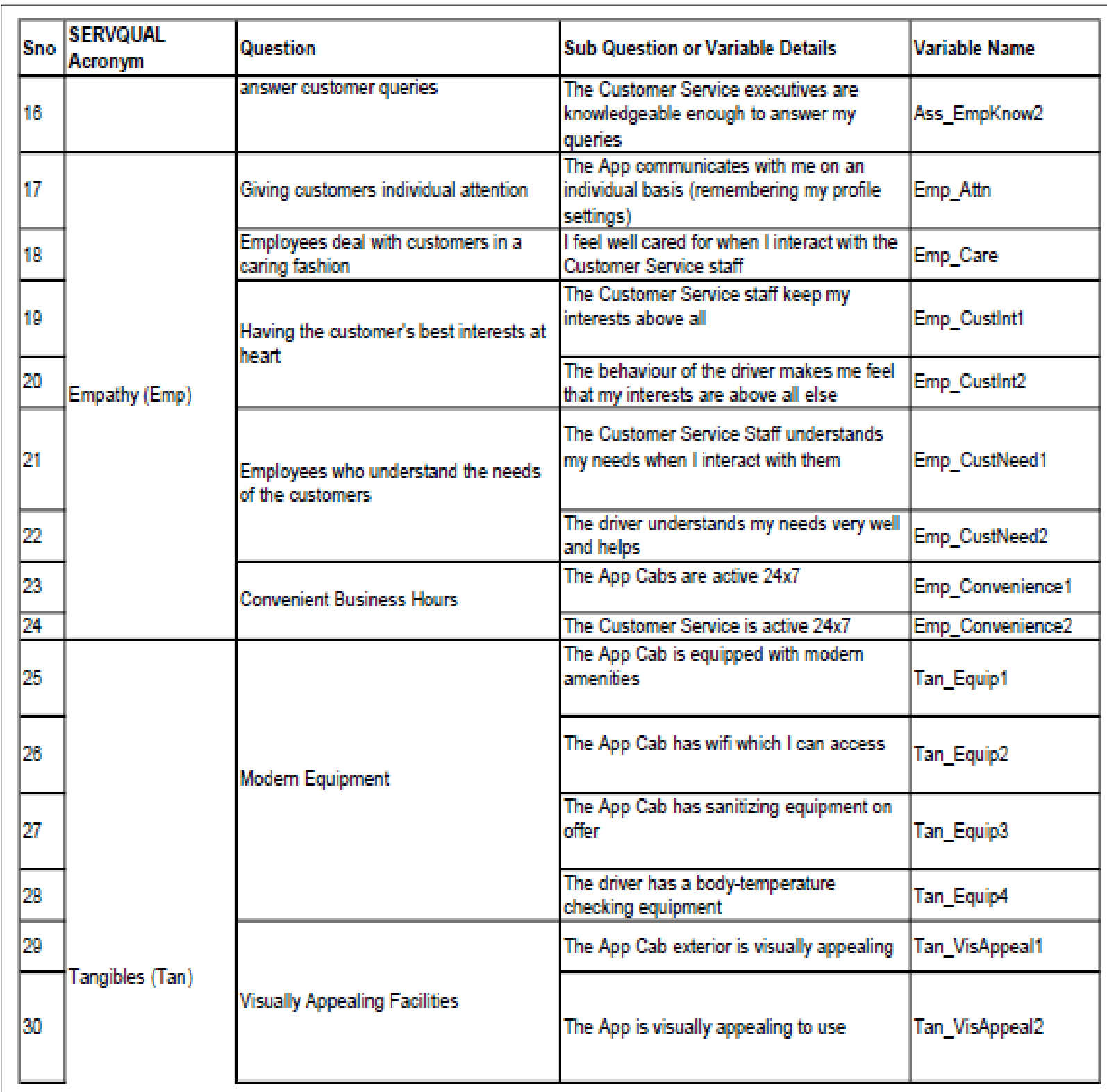

Table 1: List of 35 initial variables, as decided by the Focus Group 


\begin{tabular}{|c|c|c|c|c|}
\hline Sno & $\begin{array}{l}\text { SERVQUAL } \\
\text { Acronym }\end{array}$ & Question & Sub Question or Variable Details & Variable Name \\
\hline 31 & & \multirow{3}{*}{$\begin{array}{l}\text { Employees have a neat professional } \\
\text { appearance }\end{array}$} & The driver is always neatly dressed & Tan_EmpHygiene1 \\
\hline 32 & & & The driver always wears a clean mask & Tan_EmpHygiene2 \\
\hline 33 & & & The driver wears gloves & Tan_EmpHygiene3 \\
\hline 34 & & \multirow{3}{*}{$\begin{array}{l}\text { Visualy appealing materials associated } \\
\text { with service }\end{array}$} & The App Cab interior is comfortable & Tan_Caninterior1 \\
\hline 35 & & & The App Cab interior is visually appealing & Tan_Caninterior2 \\
\hline & & & Total Number of Variables & 35 \\
\hline
\end{tabular}

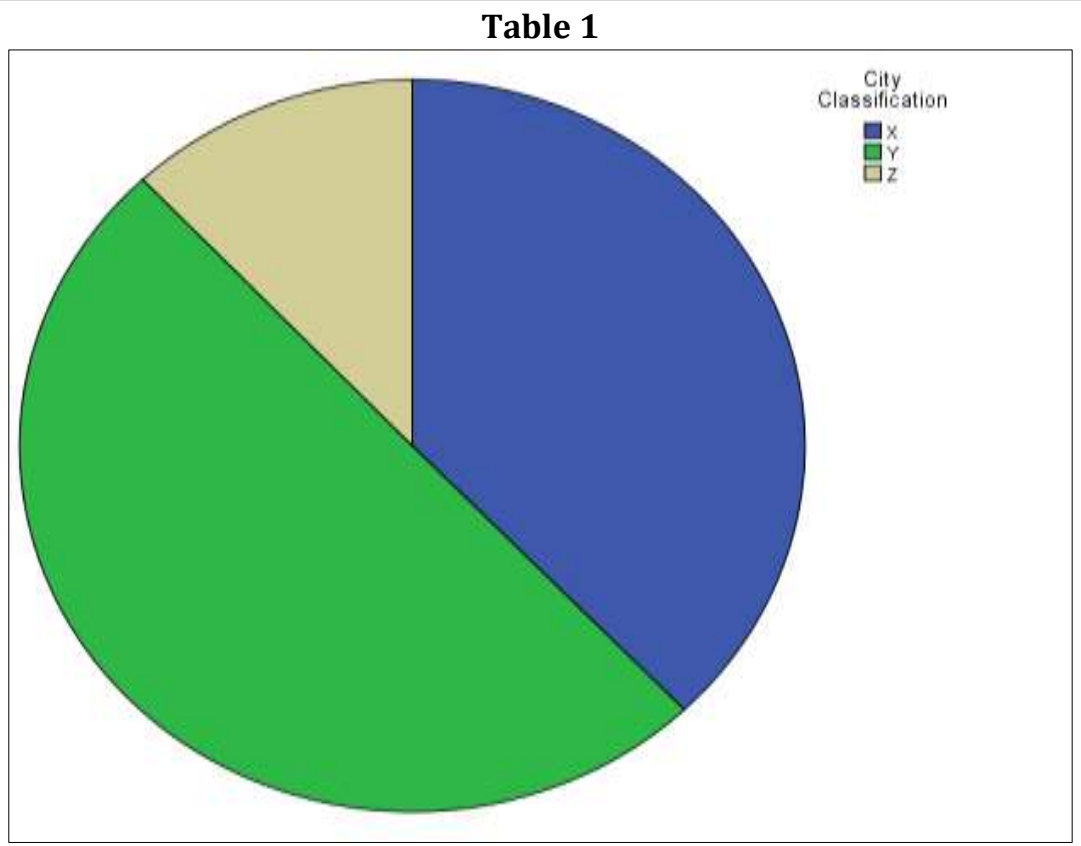

Figure 1: Respondents' demographics with respect to city classification

The data has been treated with Exploratory Factor Analysis (Varimax Rotation), using the SPSS Statistical Package and Bartlett Factor Scores recorded. (Methods to compute factor scores, and what is the "score coefficient" matrix in PCA or factor analysis?, n.d.) The age of the respondent though recorded, has not been taken cognizance of. The city of residence and home-based travel has been recorded to throw the final light of the level of satisfaction of the respondent with reference to location, using city classification.

\section{ANALYSIS AND FINDINGS}

The data collected and compiled (after necessary simulation) over 35 initial variables was put through Exploratory Factor Analysis (EFA) (with Varimax Rotation and saving the Bartlett Factor Scores). (Methods to compute factor scores, and what is the "score coefficient" matrix in PCA or factor analysis?, n.d.) The Kaiser-Meyer-Olkin Measure of Sampling Adequacy showed a healthy score of 0.900 . The EFA unearthed up six factors which accounted for $69.37 \%$ variance. The Scree Plot is shown in Fig2 and the rotated component matrix is shown in Table 2. 


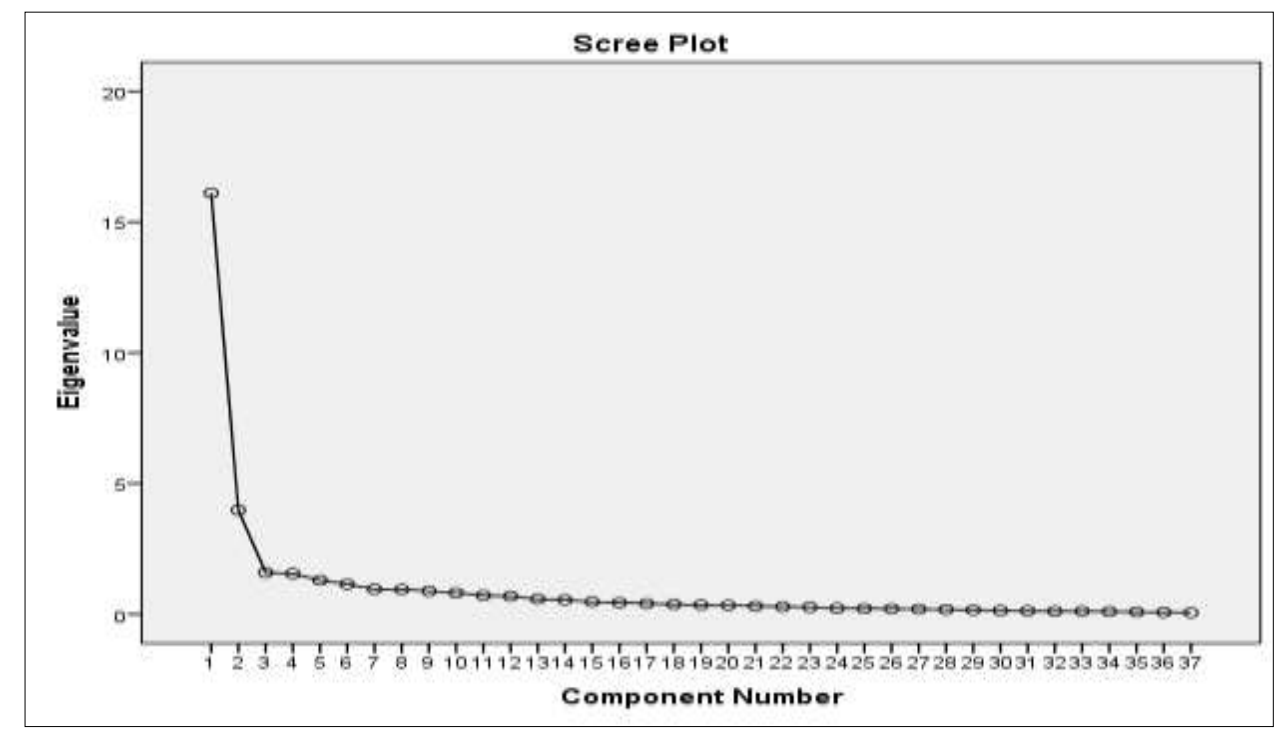

Figure 2: The Scree Plot

The six Factors are as described:

Factor1: Covid Precautions and Comfort; Factor 1 contributes to $43.369 \%$ of total variance. The customer is satisfied if he feels safe in the pandemic. Though he prefers safety and security, he also requires basic necessities such as Internet Connectivity, Modern Amenities and Comfort. The variables contributing to Factor 1 are listed in Table 3.

\begin{tabular}{|c|c|c|c|}
\hline \multirow{11}{*}{$\begin{array}{l}\text { Factor 1: Covid } \\
\text { Precautions and } \\
\text { Comfort }\end{array}$} & Variable Name & Variable Description & Factor Loading \\
\hline & Tan_EmpHygiene2 & The driver always wears a clean mask & .857 \\
\hline & Tan_EmpHygiene3 & The driver wears gloves & .841 \\
\hline & Tan_Equip4 & $\begin{array}{l}\text { The driver has a body-temperature checking } \\
\text { equipment }\end{array}$ & .830 \\
\hline & Tan_EmpHygiene1 & The driver is always neatly dressed & .692 \\
\hline & Rel_Record2 & $\begin{array}{l}\text { The App has an undertaking that the passenger is } \\
\text { not suffering from Covid or Covid-related ailment }\end{array}$ & .690 \\
\hline & Tan_Equip3 & The App Cab has sanitizing equipment on offer & .682 \\
\hline & Tan_Equip2 & The App Cab has wifi which I can access & .639 \\
\hline & Tan_Equip1 & $\begin{array}{l}\text { The App Cab is equipped with modern } \\
\text { amenities }\end{array}$ & .567 \\
\hline & Tan_CanInterior1 & The App Cab interior is comfortable & .561 \\
\hline & Tan_Vis_Appeal1 & The App Cab exterior is visually appealing & .525 \\
\hline
\end{tabular}

\section{Table 3}




\begin{tabular}{|c|c|c|c|c|c|c|}
\hline \multicolumn{7}{|c|}{ Rotated Component Matrix ${ }^{a}$} \\
\hline & \multicolumn{6}{|c|}{ Component } \\
\hline & 1 & 2 & 3 & 4 & 5 & 6 \\
\hline Rel_Promise1 & -.001 & .440 & .589 & .284 & .140 & -.005 \\
\hline iel_Promise2 & -.058 & .288 & .662 & .206 & .155 & .150 \\
\hline Rel_Dependability1 & .210 & .258 & .326 & .693 & .041 & .164 \\
\hline Rel_Dependability2 & .186 & .396 & .144 & .765 & -.007 & .132 \\
\hline Rel_Prompt & .122 & .096 & .355 & .651 & .214 & .324 \\
\hline Rel_Record1 & -.105 & .101 & .530 & .369 & .450 & -.174 \\
\hline Rel_Record2 & .690 & -.056 & -.022 & .072 & .189 & .119 \\
\hline Res_Info1 & .026 & -.014 & .813 & .208 & .174 & .182 \\
\hline Res_Info2 & -.028 & .318 & .771 & .123 & .139 & .126 \\
\hline Res_Answer & .164 & .473 & .496 & .354 & .169 & -.043 \\
\hline Ass_Emp1 & .204 & .392 & .547 & .112 & .116 & .313 \\
\hline Ass_Emp2 & .304 & .393 & .267 & .495 & .258 & .179 \\
\hline Ass_Paymt & .142 & .302 & .386 & -.056 & .713 & .127 \\
\hline Ass_Courtesy & .230 & .444 & .527 & .229 & -.033 & .171 \\
\hline Ass_EmpKnow1 & .352 & .341 & .678 & -.006 & .192 & .072 \\
\hline Ass_EmpKnow2 & .161 & .607 & .245 & .368 & .260 & .184 \\
\hline Emp_Attn & .141 & .173 & .442 & .192 & .556 & .139 \\
\hline Emp_Care & .167 & .554 & .346 & .141 & .280 & .332 \\
\hline mp_Custlr & .206 & .616 & .238 & .097 & .404 & .062 \\
\hline Emp_Custlnt2 & .196 & .689 & .342 & .189 & .168 & .137 \\
\hline Emp_CustNeed1 & .141 & .777 & .166 & .310 & .047 & .071 \\
\hline Emp_CustNeed2 & .228 & .623 & .261 & .381 & .130 & .144 \\
\hline Emp_Con & .087 & 73 & .258 & .182 & .123 & .816 \\
\hline Emp_Convenience2 & .198 & .172 & .097 & .179 & .035 & .860 \\
\hline Tan_Equip1 & .567 & .546 & .131 & -.063 & .117 & .138 \\
\hline Tan_Equip2 & .639 & .222 & -.148 & .205 & .342 & .110 \\
\hline Tan_Equip3 & .682 & .157 & .048 & .211 & .343 & .100 \\
\hline Tan_Equip4 & .830 & .199 & -.097 & .220 & .145 & .031 \\
\hline Tan_Vis_Appeal1 & .525 & .462 & .226 & .197 & .111 & .178 \\
\hline Tan_VisAppeal2 & .249 & .238 & .225 & .385 & .468 & .075 \\
\hline Tan_EmpHygiene1 & .692 & .197 & .359 & .100 & -.098 & .270 \\
\hline Tan_EmpHygiene2 & .857 & .172 & .180 & -.097 & -.058 & -.038 \\
\hline Tan_EmpHygiene3 & .841 & .095 & -.002 & .130 & -.137 & -.007 \\
\hline Tan_CanInterior1 & .561 & .395 & .431 & .194 & .014 & .129 \\
\hline Tan_CanInterior2 & .542 & .623 & .273 & .037 & .031 & .085 \\
\hline
\end{tabular}

Table 2 
Factor2: Service at Contact Point; The behaviour and knowledge displayed by the Customer Service and Driver (Customer Contact Points). The customer's needs have to be understood and catered to. The variables contributing to Factor2 are listed in Table 4.

\begin{tabular}{|c|c|c|c|}
\hline \multirow{9}{*}{$\begin{array}{c}\text { Factor 2: } \\
\text { Service } \\
\text { at } \\
\text { Contact } \\
\text { Point }\end{array}$} & Variable Name & Variable Description & Factor Loading \\
\hline & Emp_CustNeed1 & $\begin{array}{l}\text { The Customer Service Staff understands my } \\
\text { needs when I interact with them }\end{array}$ & .777 \\
\hline & Emp_Custlnt2 & $\begin{array}{l}\text { The behaviour of the driver makes me feel that } \\
\text { my interests are above all else }\end{array}$ & 689 \\
\hline & Tan_CanInterior2 & The App Cab interior is visually appealing & .623 \\
\hline & Emp_CustNeed2 & $\begin{array}{l}\text { The driver understands my needs very well and } \\
\text { helps }\end{array}$ & 623 \\
\hline & Emp_Custlnt1 & $\begin{array}{l}\text { The Customer Service staff keep my interests } \\
\text { above all }\end{array}$ & .616 \\
\hline & Ass_EmpKnow2 & $\begin{array}{l}\text { The Customer Service executives are } \\
\text { knowledgeable enough to answer my queries }\end{array}$ & 607 \\
\hline & Emp_Care & $\begin{array}{l}\text { I feel well cared for when I interact with the } \\
\text { Customer Service staff }\end{array}$ & .554 \\
\hline & Ass_Emp2 & $\begin{array}{l}\text { Whenever I have interacted with the customer } \\
\text { service of the App Cab, I have felt confident } \\
\text { regarding their efforts }\end{array}$ & .393 \\
\hline
\end{tabular}

Table 4

Factor 3: Travel time-efficiency and surety; The customer is particular of the promptness of the App $\mathrm{Cab}$ and its service. He also appreciates if the driver has good driving skills. The variables contributing to Factor3 are listed in Table 5.

Factor 4: Customer Care Efficiency; The customer is concerned about the level of responsiveness of the App $\mathrm{Cab}$ and its Customer Care. The variables contributing to Factor 4 are listed in Table 6.
Factor 5: Transparency in Dealings; The customer is insistent on transparency when dealing with money or information. The variables contributing to Factor5 are listed in Table 7.

Factor 6: 24x7 Service; The customer is particular of $24 \times 7$ service; The variables contributing to Factor6 are listed in Table 8. 


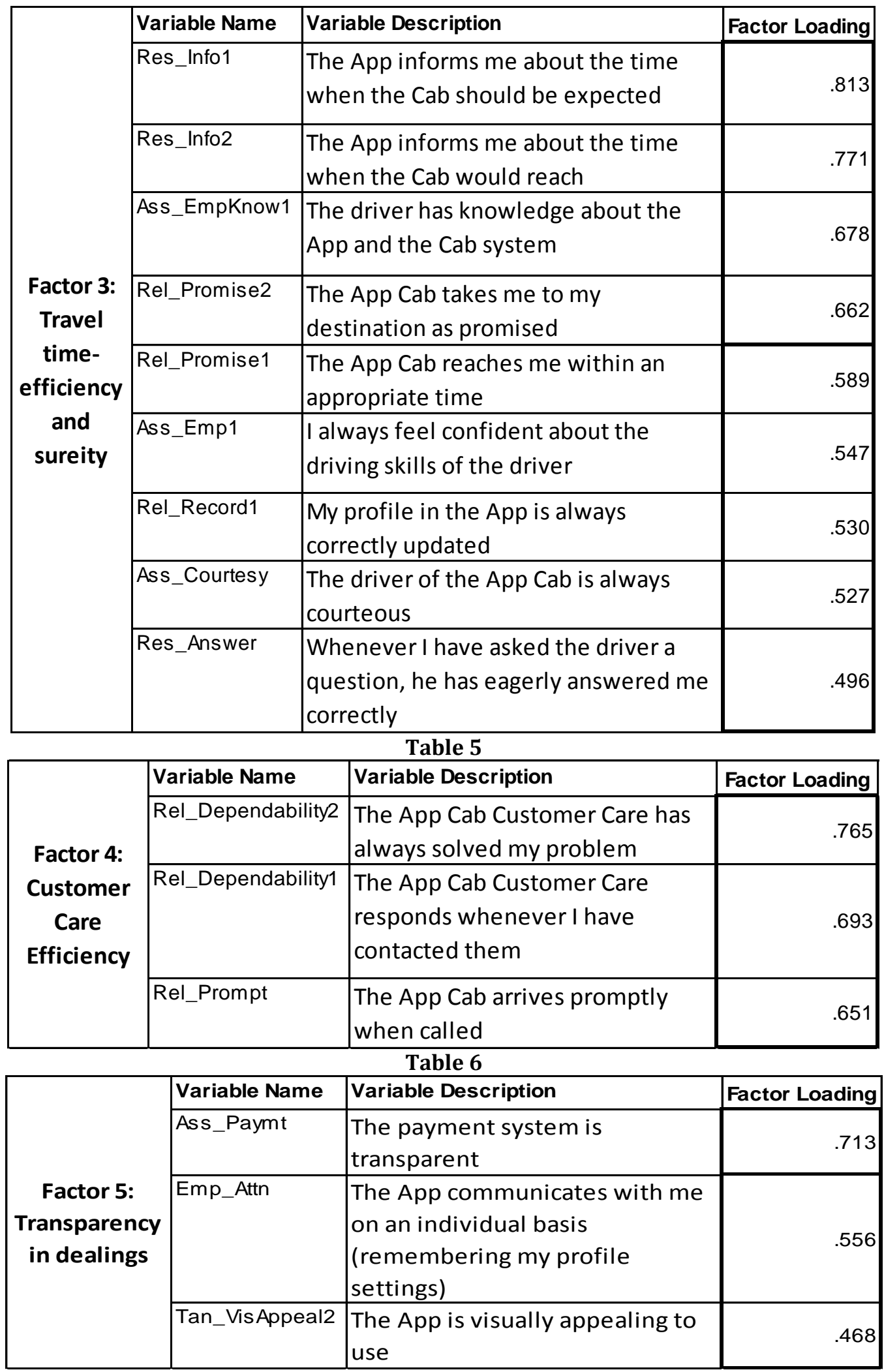

Table 7 


\begin{tabular}{|c|l|l|r|}
\hline \multirow{2}{*}{$\begin{array}{c}\text { Factor 6: } \\
\mathbf{2 4 x 7}\end{array}$} & Variable Name & Variable Description & Factor Loading \\
\cline { 2 - 4 } Service & Emp_Convenience2 & $\begin{array}{l}\text { The Customer Service is active } \\
24 \times 7\end{array}$ & .860 \\
\cline { 2 - 4 } & Emp_Convenience1 & The App Cabs are active 24x7 & .816 \\
\hline
\end{tabular}

Table 8

At this stage, an independent samples median test was conducted on Factor Scores over City Classification to check if there are any variation of opinions of customers (measured by the saved Factor Scores) over the different classes of cities. No significant variation of customer opinion is noted. The analysis is shown in Table 9.

\begin{tabular}{|c|c|c|c|c|}
\hline \multicolumn{5}{|c|}{ Hypothesis Test Summary } \\
\hline & Null Hypothesis & Test & Sig. & Decision \\
\hline 1 & $\begin{array}{l}\text { The medians of Covid Precautions } \\
\text { and Comfort are the same across } \\
\text { categories of City Classification. }\end{array}$ & $\begin{array}{l}\text { Independent- } \\
\text { Samples } \\
\text { Median Test }\end{array}$ & .981 & $\begin{array}{l}\text { Retain the } \\
\text { null } \\
\text { hypothesis. }\end{array}$ \\
\hline 2 & $\begin{array}{l}\text { The medians of Service at Contact } \\
\text { Point are the same across } \\
\text { categories of City Classification. }\end{array}$ & $\begin{array}{l}\text { Independent- } \\
\text { Samples } \\
\text { Median Test }\end{array}$ & .102 & $\begin{array}{l}\text { Retain the } \\
\text { null } \\
\text { hypothesis. }\end{array}$ \\
\hline 3 & $\begin{array}{l}\text { The medians of Promptness and } \\
\text { Surety of Service Delivery are the } \\
\text { same across categories of City } \\
\text { Classification. }\end{array}$ & $\begin{array}{l}\text { Independent- } \\
\text { Samples } \\
\text { Median Test }\end{array}$ & .274 & $\begin{array}{l}\text { Retain the } \\
\text { null } \\
\text { hypothesis. }\end{array}$ \\
\hline 4 & $\begin{array}{l}\text { The medians of Responsiveness of } \\
\text { Customer Care are the same } \\
\text { across categories of City } \\
\text { Classification. }\end{array}$ & $\begin{array}{l}\text { Independent- } \\
\text { Samples } \\
\text { Median Test }\end{array}$ & .268 & $\begin{array}{l}\text { Retain the } \\
\text { null } \\
\text { hypothesis. }\end{array}$ \\
\hline 5 & $\begin{array}{l}\text { The medians of Transparency in } \\
\text { Dealings are the same across } \\
\text { categories of City Classification. }\end{array}$ & $\begin{array}{l}\text { Independent- } \\
\text { Samples } \\
\text { Median Test }\end{array}$ & .268 & $\begin{array}{l}\text { Retain the } \\
\text { null } \\
\text { hypothesis. }\end{array}$ \\
\hline 6 & $\begin{array}{l}\text { The medians of } 24 \times 7 \text { Service are } \\
\text { the same across categories of City } \\
\text { Classification. }\end{array}$ & $\begin{array}{l}\text { Independent- } \\
\text { Samples } \\
\text { Median Test }\end{array}$ & .463 & $\begin{array}{l}\text { Retain the } \\
\text { null } \\
\text { hypothesis. }\end{array}$ \\
\hline & ymptotic significances are displaye & The significa & el is .0 & \\
\hline
\end{tabular}

Table 9

\section{CONCLUSIONS AND RECOMMENDATIONS}

a. Managerial Implications

The factors unearthed could guide the marketing strategies of App Cab organizations towards enhanced customer satisfaction. Customers, wary of the spread of the SARS CoV19 virus put Covid-related precautions and some basic comforts above all else. Much importance is also given to information-proliferation and travel-time efficiency and here, the Customer Care and drivers play a major role. It is intriguing to note that payment systems and $24 \times 7$ service are the last 
factors to be considered, perhaps because the cost of the pandemic overshadows all other costs in the mind of the human being. The app cab organizations should educate their staff and drivers to respond to customers' needs accordingly. The research shows that performance is not varied over the different type of cities of the nation.

The data collected has been through convenience sampling and thus, is not likely to give exact results regarding types of cities. However, the results could guide such organizations to have individual feedback systems for different classes of cities and monitor the same closely.

\section{b. Research Implications}

This research lays the foundation for exploration of Factor Relationships through Partial Least Squares and Structural Equation Modelling. Further, if the data is re-collected with multi stage stratified sampling, considering the demographic factors as age, gender and education, it could guide the researcher towards market segmentation and the results could be put to use to target and position offerings.

\section{REFERENCES}

1. Bhuvaneswari, R., Varghese, J., Rajasekaran, S., \& Muthulakshmi, V. (2018). DIGITAL MARKETING USING SMART PHONE BOOKING CAB ON CONSUMER PERSPECTIVE. International Journal of Technical Research \& Science, 3(XI), 344 - 348. doi:10.30780/IJTRS.V3.I10.2018.003

2. Buttle, F. (1996). SERVQUAL: review, critique, research agenda. European Journal of Marketing, 30(1), 8 - 32. Retrieved from http://140.117.77.118/2009/m954011064/References/20 080927Buttle1994

3. Classification of Indian cities. (2021, Mar 20). Retrieved from https://en.wikipedia.org/wiki/: https://en.wikipedia.org/wiki/Classification_of_Indian_c ities

4. Ghosh, R., \& Mitra, D. (2019, May). AN ANALYTICAL STUDY ON THE SATISFACTIONLEVEL OF APP CAB DRIVERS IN KOLKATA. IMPACT: International Journal of Research in Humanities, Arts and Literature (IMPACT: IJRHAL), 7(5), 289 - 298.

5. Le-Klähn, D.-T., Hall, C. M., \& Gerike, R. (2014). Analysis of Visitor Satisfaction with Public Transport in Munich. Journal of Public Transportation, 17(3), 68 85.

6. Methods to compute factor scores, and what is the "score coefficient" matrix in PCA or factor analysis? (n.d.). Retrieved Jan 18, 2021, from https://stats.stackexchange.com: https://stats.stackexchange.com/questions/126885/metho ds-to-compute-factor-scores-and-what-is-the-scorecoefficient-matrix-in

7. Ola Cabs: Ride Safe. (n.d.). Retrieved Jan 17, 2021, fromhttps://www.olacabs.com: https://www.olacabs.com/RideSafeIndia
8. Ola launches '10 Steps to a Safer Ride' for driverpartners and customers as services resume in 100+ cities in green and orange zones across the country. (n.d.). Retrieved Jan 17, 2021, from https://www.olacabs.com:

https://www.olacabs.com/media/in/press/ola-launches10-steps-to-a-safer-ride-for-driver-partners-andcustomers-as-services-resume-in-100-cities-in-greenand-orange-zones-across-the-country

9. Our approach to COVID-19. (n.d.). Retrieved Jan 17, 2021, from https://www.uber.com: https://www.uber.com/in/en/coronavirus/

10. Pandya, U., Rungta, R., \& Iyer, G. (2017, Mar). Impact of use of Mobile Apps of Ola Cabs and Taxi for Sure on Yellow and Black Cabs. Pacific Business Review International, 9(9), 91 - 105.

11. Sivasakthi, D., Nandini, C., Priyadharshini, R., \& Vanathi, D. (2019, Mar). TAXI SERVICES IN INDIA. EPRA International Journal of Research and Development (IJRD), 4(3), 34 - 39.

12. Thilakaratne, N., \& Jayaratne, P. (2019). Evaluate and Identify the Factors Impact on Selecting a Mobile AppBased Taxi Service in Sri Lanka (Users' Perspective). Journal of the Eastern Asian Society for Transportation studies, 13, 2466 - 2486.

13. Uber announces new safety features amid COVID-19, masks now mandatory for both driver and riders. (2020, May 18). Retrieved from https://www.thehindu.com: https://www.thehindu.com/news/national/uberannounces-new-safety-features-amid-covid-19-masksnow-mandatory-for-both-driver-andriders/article31612490.ece 